\title{
Taxonomy of the genus Cupriavidus: a tale of lost and found
}

\author{
Peter Vandamme and Tom Coenye \\ Laboratorium voor Microbiologie, Faculteit Wetenschappen, Universiteit Gent, \\ K.L. Ledeganckstraat 35, B-9000 Gent, Belgium
}

Correspondence

Peter Vandamme

peter.vandamme@ugent.be
Cupriavidus necator was described by Makkar \& Casida (1987) to accommodate a non-obligate bacterial predator of various Gram-negative and Gram-positive soil bacteria and fungi (Byrd et al., 1985; Sillman \& Casida, 1986; Zeph \& Casida, 1986). The single known isolate, strain $\mathrm{N}-1^{\mathrm{T}}$ ( = LMG $8453^{\mathrm{T}}$ ), was obtained from soil in the vicinity of University Park, PA, USA. When confronted with Agromyces ramosus mycelia during the so-called 'attack-counterattack' predation process, this strain produces several chemical signals, one of which chelates copper. C. necator is highly resistant to copper and its growth initiation is strongly stimulated by copper (Makkar \& Casida, 1987).

Makkar \& Casida (1987) reported the DNA base ratio and a wide range of morphological, biochemical and nutritional properties of this organism but did not examine its phylogenetic position through $16 \mathrm{~S}$ rRNA studies as is currently standard procedure in prokaryotic taxonomy. They noticed several characteristics their organism shared with members of the genus Alcaligenes, which, at that time, comprised multiple species, including Alcaligenes faecalis (the type species), Alcaligenes xylosoxidans and allied species (now all classified in the genus Achromobacter; Yabuuchi et al., 1998) and Alcaligenes eutrophus [first reclassified in the genus Ralstonia (Yabuuchi et al., 1995) and recently transferred again, to the novel genus Wautersia

Published online ahead of print on 18 June 2004 as DOI 10.1099/ ijs.0.63247-0.
(Vaneechoutte et al., 2004)]. However, a few unique biochemical characteristics and the spectacular predatory activity convinced Makkar \& Casida (1987) to classify their strain into a novel genus and species.

In the course of a long-term study of the biodiversity of various Burkholderia cepacia-like bacteria, we discovered a nearly complete $16 \mathrm{~S}$ rRNA gene sequence that was deposited for $C$. necator in the public database under the accession number AF191737. This sequence was very similar to that of Wautersia eutropha isolates. Fig. 1 shows the result of the comparison of the $16 \mathrm{~S}$ rRNA gene sequence of $C$. necator LMG $8453^{\mathrm{T}}$ with those of strains representing Wautersia, Ralstonia and other $\beta$-Proteobacteria. The phylogenetic analysis, including a bootstrap analysis with 1000 replicates, was performed using the BioNumerics 3.5 software package (Applied Maths) and was based on the neighbour-joining method using nearly complete sequences and excluding undetermined base positions from the calculations. The similarity level between the 16S rRNA gene sequences of strains C. necator LMG $8453^{\mathrm{T}}$ and W. eutropha LMG $1199^{\mathrm{T}}$ was $99 \cdot 7 \%$.

We subsequently compared the whole-cell protein electrophoretic profiles of $C$. necator and W. eutropha isolates. SDSPAGE of whole-cell proteins was performed as described previously (Pot et al., 1994), after growth of the isolates for $48 \mathrm{~h}$ at $37^{\circ} \mathrm{C}$ on trypticase soy agar (BBL). Densitometric analysis, normalization and interpolation of the protein profiles were performed using the GelCompar 4.2 software 


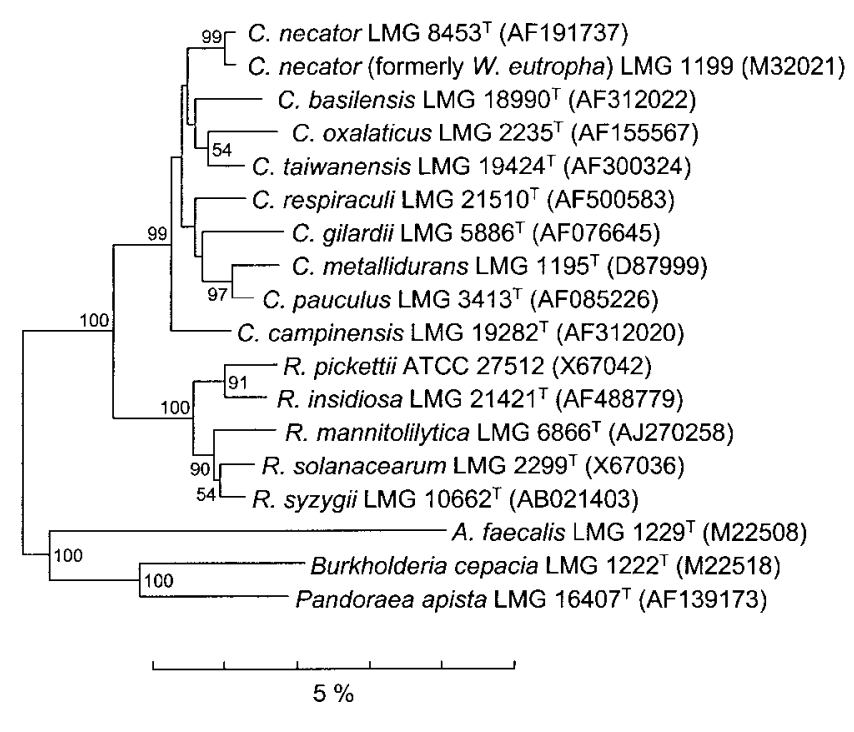

Fig. 1. Rooted phylogenetic tree based upon 16S rRNA gene sequence similarity of the genera Cupriavidus and Ralstonia and representative species of the $\beta$-Proteobacteria. Cluster analysis was based upon the neighbour-joining method with Alcaligenes faecalis LMG $1229^{\top}$ as the outgroup root. The scale bar represents $5 \%$ sequence divergence. Numbers at branch-points are percentages of 1000 bootstrap resamplings that support the topology of the tree (only values above $50 \%$ are presented).

package (Applied Maths). The whole-cell protein profiles of C. necator LMG $8453^{\mathrm{T}}$ and of W. eutropha LMG $1199^{\mathrm{T}}$ $\left(=\mathrm{TF}^{\mathrm{T}}{ }^{\mathrm{T}}\right)$ and LMG $1201 \quad(=\mathrm{H} 16)$, two established $W$. eutropha reference strains (Jenni et al., 1988), were very similar (Fig. 2).

DNA-DNA hybridization experiments were subsequently performed with photobiotin-labelled probes in microplate wells as described by Ezaki et al. (1989), using an HTS7000 Bio Assay Reader for the fluorescence measurements. The hybridization temperature was $50^{\circ} \mathrm{C}$. DNA was prepared as described by Pitcher et al. (1989). The DNA-DNA binding values obtained were $100 \%$ between $W$. eutropha LMG $1199^{\mathrm{T}}$ and LMG 1201 (which is in perfect agreement with a previously published value; Jenni et al., 1988), $79 \%$ between W. eutropha LMG $1199^{\mathrm{T}}$ and C. necator $\mathrm{LMG} 8453^{\mathrm{T}}$ and $92 \%$ between W. eutropha LMG 1201 and C. necator LMG $8453^{\mathrm{T}}$. These data indicate unambiguously that the three isolates represent the same genospecies and confirm that, in the genera Ralstonia and Wautersia, high protein electrophoretic similarity correlates with a high level of DNA-DNA hybridization (Coenye et al., 1999, 2003a; Vandamme et al., 1999; Goris et al., 2001).

Given the reported difference in DNA base ratio for the two taxa $[67 \mathrm{~mol} \% \mathrm{G}+\mathrm{C}$ for W. eutropha (Goris et al., 2001) versus $57 \mathrm{~mol} \%$ for C. necator (Makkar \& Casida, 1987)], we determined the DNA base ratio of C. necator LMG $8453^{\mathrm{T}}$ by two approaches. The DNA was enzymically degraded into nucleosides as described by Mesbah et al. (1989). The obtained nucleoside mixture was then separated by HPLC using a Waters SymmetryShield C8 column thermostatted at $37^{\circ} \mathrm{C}$. The solvent was $0.02 \mathrm{M} \mathrm{NH}_{4} \mathrm{H}_{2} \mathrm{PO}_{4}(\mathrm{pH} 4.0)$ with $1.5 \%$ acetonitrile. Non-methylated lambda phage DNA (Sigma) was used as the calibration reference. In addition, the DNA base ratio was also determined by thermal denaturation and calculated as described by De Ley (1970). The former method yielded a G $+C$ content of $65 \mathrm{~mol} \%$, the latter $66 \mathrm{~mol} \%$. These values are similar to values previously determined for W. eutropha (Goris et al., 2001; Jenni et al., 1988) and clearly different from the value for $C$. necator determined by Makkar \& Casida (1987). We believe that this difference is due to experimental error in the original study.

The results of the extensive biochemical characterization of C. necator LMG $8453^{\mathrm{T}}$ generally correlate well with those provided by Yabuuchi et al. (1995) and De Baere et al. (2001) for W. eutropha. Both organisms are reported as Gram-negative, peritrichously flagellated bacteria with an oxidative metabolism. They produce catalase and oxidase and reduce nitrate to nitrite but exhibit no DNase activity. They hydrolyse Tween 80 , but not urea, gelatin or aesculin. The remarkable resistance to (and growth stimulation by) copper was one of the key arguments for excluding strain LMG $8453^{\mathrm{T}}$ from the genus Alcaligenes (Makkar \& Casida, 1987). However, resistance to copper and a range of other metals is well-documented for species now classified in Wautersia and is often plasmid-borne (Mergeay et al., 2003).

The results of the present study indicate that, in the 1980s, the isolate described by Makkar \& Casida (1987) should have been classified as Alcaligenes eutrophus Davis 1969. Alcaligenes eutrophus was reclassified in the novel genus Ralstonia, together with two former Burkholderia species, Burkholderia solanacearum and Burkholderia pickettii (Yabuuchi et al., 1995). Subsequently, the genus Ralstonia was divided into Ralstonia sensu stricto and the novel genus

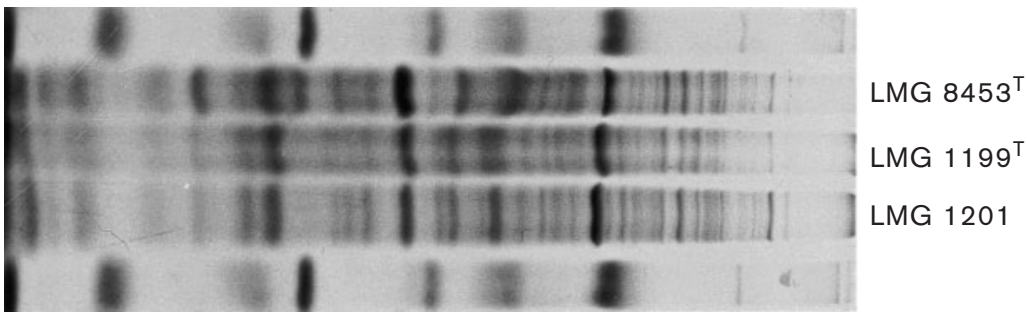

Fig. 2. Whole-cell protein profiles of C. necator LMG $8453^{\top}$ and of $W$. eutropha strains LMG $1199^{\top}$ and LMG 1201. 
Wautersia, with W. eutropha as the type species. As outlined above, the name $C$. necator was validly published in 1987 and the names Ralstonia and Wautersia were only published much later. Rule 23a of the International Code of Nomenclature of Bacteria (Lapage et al., 1992) specifies that each taxon above a species can bear only one correct name, that is, the earliest that is in accordance with the Rules of the Code.

In addition, the nomenclatural type of a taxon is that element of the taxon with which it is permanently associated. Rule 42 specifies that, in the case of subspecies, species, subgenera and genera, if two or more taxa of the same rank are united, the oldest legitimate name or epithet is retained. Therefore, the genus name Wautersia is a later synonym of the genus Cupriavidus, for which the type species is C. necator (Rule 15 of the Code). Furthermore, the Code stipulates that the type determines the application of the name of a taxon if the taxon is subsequently divided or united with another taxon (Rule 17). While renaming and subsequent further renaming of bacterial species causes confusion and, not the least, irritation in the wider microbiological community, adhering to the rules of nomenclature is essential for establishing a truly systematic taxonomy. Therefore, while it may be inconvenient to deal with two name changes for a bacterium within one year (i.e. Ralstonia to Wautersia to Cupriavidus), in the long run, such reorganizations of the taxonomy of organisms are warranted as new data come to light.

Conforming to Rule $37 \mathrm{a}(1)$, that the name of a taxon must be changed if the nomenclatural type is excluded, we propose that the name Wautersia be replaced by Cupriavidus and that all species of the genus Wautersia be considered species of the genus Cupriavidus. We consequently propose to reclassify the remaining Wautersia species, i.e. Wautersia basilensis (Steinle et al. 1999) Vaneechoutte et al. 2004, Wautersia campinensis (Goris et al. 2001) Vaneechoutte et al. 2004, Wautersia gilardii (Coenye et al. 1999) Vaneechoutte et al. 2004, Wautersia metallidurans (Goris et al. 2001) Vaneechoutte et al. 2004, Wautersia oxalatica (Sahin et al. 2000) Vaneechoutte et al. 2004, Wautersia paucula (Vandamme et al. 1999) Vaneechoutte et al. 2004, Wautersia respiraculi (Coenye et al. 2003b) Vaneechoutte et al. 2004 and Wautersia taiwanensis (Chen et al. 2001) Vaneechoutte et al. 2004, into the genus Cupriavidus.

In contrast with the etymology presented by Makkar \& Casida (1987), the gender of the genus name Cupriavidus is masculine [Rule 65(2)]. We therefore propose to reclassify the former Wautersia species as follows.

\section{Emended description of the genus Cupriavidus}

The description of the emended genus Cupriavidus is based on that presented by Makkar \& Casida (1987) with some modifications. Cells are Gram-negative, peritrichously flagellated rods. Chemoheterotrophic or chemolithotrophic. The metabolism is oxidative. Several amino acids are used as sole carbon and nitrogen sources. Catalase and oxidase activity is produced. Resistance to various metals is widespread. The respiratory quinone Q8 has been reported in W. eutropha (Yabuuchi et al., 1995). The DNA G +C content is between 63 and $69 \mathrm{~mol} \%$. Species occur in soil and human clinical specimens, particularly in samples from debilitated patients. The type species is Cupriavidus necator.

\section{Description of Cupriavidus basilensis comb. nov.}

Cupriavidus basilensis [N.L. masc. adj. basilensis from Basilea (Basel), where the type strain was isolated].

Basonym: Ralstonia basilensis Steinle et al. 1999.

The description is identical to that given for Wautersia basilensis by Vaneechoutte et al. (2004). The type strain is LMG $18990^{\mathrm{T}}\left(=\mathrm{DSM} 11853^{\mathrm{T}}\right)$.

\section{Description of Cupriavidus campinensis comb. nov.}

Cupriavidus campinensis (N.L. masc. adj. campinensis from the Kempen or Campine, the geographical region of northeast Belgium where this bacterium was initially isolated).

Basonym: Ralstonia campinensis Goris et al. 2001.

The description is identical to that given for Wautersia campinensis by Vaneechoutte et al. (2004). The type strain is LMG $19282^{\mathrm{T}}\left(=\right.$ CCUG $\left.44526^{\mathrm{T}}\right)$.

\section{Description of Cupriavidus gilardii comb. nov.}

Cupriavidus gilardii (N.L. gen. n. gilardii of Gilardi, named in honour of G. L. Gilardi, an American microbiologist).

Basonym: Ralstonia gilardii Coenye et al. 1999.

The description is identical to that given for Wautersia gilardii by Vaneechoutte et al. (2004). The type strain is LMG $5886^{\mathrm{T}}\left(=\right.$ CCUG $\left.38401^{\mathrm{T}}\right)$.

\section{Description of Cupriavidus metallidurans comb. nov.}

Cupriavidus metallidurans (N.L. masc. part. adj. metallidurans enduring metal, to indicate that these bacteria are able to survive high heavy-metal concentrations).

Basonym: Ralstonia metallidurans Goris et al. 2001.

The description is identical to that given for Wautersia metallidurans by Vaneechoutte et al. (2004). The type strain is LMG $1195^{\mathrm{T}}\left(=\mathrm{DSM} 2839^{\mathrm{T}}\right)$.

\section{Description of Cupriavidus oxalaticus comb. nov.}

Cupriavidus oxalaticus (N.L. masc. adj. oxalaticus pertaining to oxalate). 
Basonym: Ralstonia oxalatica (ex Khambata and Bhat 1953) Sahin et al. 2000.

The description is identical to that given for Wautersia oxalatica by Vaneechoutte et al. (2004). The type strain is LMG $2235^{\mathrm{T}}\left(=\right.$ CCUG $2086^{\mathrm{T}}=$ DSM $\left.1105^{\mathrm{T}}\right)$.

\section{Description of Cupriavidus pauculus comb. nov.}

Cupriavidus pauculus (L. masc. adj. pauculus rare, few, to indicate that these strains only sporadically cause human infections).

Basonym: Ralstonia paucula Vandamme et al. 1999.

The description is identical to that given for Wautersia paucula by Vaneechoutte et al. (2004). The type strain is LMG $3244^{\mathrm{T}}\left(=\right.$ CCUG $\left.12507^{\mathrm{T}}\right)$.

\section{Description of Cupriavidus respiraculi comb. nov.}

Cupriavidus respiraculi (L. gen. n. respiraculi of the respiratory system).

Basonym: Ralstonia respiraculi Coenye et al. 2003.

The description is identical to that given for Wautersia respiraculi by Vaneechoutte et al. (2004). The type strain is LMG $21510^{\mathrm{T}}\left(=\right.$ CCUG $\left.46809^{\mathrm{T}}\right)$.

\section{Description of Cupriavidus taiwanensis comb. nov.}

Cupriavidus taiwanensis (N.L. masc. adj. taiwanensis from Taiwan, where root-nodulating strains were isolated).

Basonym: Ralstonia taiwanensis Chen et al. 2001.

The description is identical to that given for Wautersia taiwanensis by Vaneechoutte et al. (2004). The type strain is LMG $19424^{\mathrm{T}}\left(=\right.$ CCUG $\left.44338^{\mathrm{T}}\right)$.

\section{Acknowledgements}

T.C. and P.V. are indebted to the Fund for Scientific Research Flanders (Belgium) for a position as postdoctoral fellow and research grants, respectively. T. C. also acknowledges support from the Belgian Federal Government (Federal Office for Scientific, Technical and Cultural Affairs). We thank J. Euzéby, B. J. Tindall and H. G. Trüper for clarifying the nomenclatural consequences of the detected synonymy.

\section{References}

Byrd, J. J., Zeph, L. R. \& Casida, L. E. (1985). Bacterial control of Agromyces ramosus in soil. Can J Microbiol 31, 1157-1163.

Chen, W.-M., Laevens, S., Lee, T.-M., Coenye, T., De Vos, P., Mergeay, M. \& Vandamme, P. (2001). Ralstonia taiwanensis sp. nov., isolated from root nodules of Mimosa species and sputum of a cystic fibrosis patient. Int J Syst Evol Microbiol 51, 1729-1735.

Coenye, T., Falsen, E., Vancanneyt, M., Hoste, B., Govan, J. R. W., Kersters, K. \& Vandamme, P. (1999). Classification of some
Alcaligenes faecalis-like isolates from the environment and human clinical samples as Ralstonia gilardii sp. nov. Int J Syst Bacteriol 49, 405-413.

Coenye, T., Goris, J., De Vos, P., Vandamme, P. \& LiPuma, J. J. (2003a). Classification of Ralstonia pickettii-like isolates from the environment and various clinical samples as Ralstonia insidiosa sp. nov. Int J Syst Evol Microbiol 53, 1075-1080.

Coenye, T., Vandamme, P. \& LiPuma, J. J. (2003b). Ralstonia respiraculi sp. nov., isolated from the respiratory tract of cystic fibrosis patients. Int J Syst Evol Microbiol 53, 1339-1342.

De Baere, T., Steyaert, S., Wauters, G., De Vos, P., Goris, J., Coenye, T., Suyama, T., Verschraegen, G. \& Vaneechoutte, M. (2001). Classification of Ralstonia pickettii biovar 3/'thomasii' strains (Pickett 1994) and of new isolates related to nosocomial recurrent meningitis as Ralstonia mannitolytica sp. nov. Int J Syst Evol Microbiol 51, 547-558.

De Ley, J. (1970). Reexamination of the association between melting point, buoyant density, and chemical base composition of deoxyribonucleic acid. J Bacteriol 101, 738-754.

Ezaki, T., Hashimoto, Y. \& Yabuuchi, E. (1989). Fluorometric deoxyribonucleic acid-deoxyribonucleic acid hybridization in microdilution wells as an alternative to membrane filter hybridization in which radioisotopes are used to determine genetic relatedness among bacterial strains. Int J Syst Bacteriol 39, 224-229.

Goris, J., De Vos, P., Coenye, T. \& 7 other authors (2001). Classification of metal-resistant bacteria from industrial biotopes as Ralstonia campinensis sp. nov., Ralstonia metallidurans sp. nov., and Ralstonia basilensis Steinle et al. 1998 emend. Int J Syst Evol Microbiol 51, 1773-1782.

Jenni, B., Realini, L., Aragno, M. \& Tamer, Ü. (1988). Taxonomy of non $\mathrm{H}_{2}$-lithotrophic, oxalate-oxidizing bacteria related to Alcaligenes eutrophus. Syst Appl Microbiol 10, 126-133.

Lapage, S. P., Sneath, P. H. A., Lessel, E. F., Skerman, V. B. D., Seeliger, H. P. R. \& Clark, W. A. (editors) (1992). International Code of Nomenclature of Bacteria (1990 Revision). Bacteriological Code. Washington, DC: American Society for Microbiology.

Makkar, N. S. \& Casida, L. E., Jr (1987). Cupriavidus necator gen. nov., sp. nov.: a nonobligate bacterial predator of bacteria in soil. Int J Syst Bacteriol 37, 323-326.

Mergeay, M., Monchy, S., Vallaeys, T. \& 7 other authors (2003). Ralstonia metallidurans, a bacterium specifically adapted to toxic metals: towards a catalogue of metal-responsive genes. FEMS Microbiol Rev 27, 385-410.

Mesbah, M., Premachandran, U. \& Whitman, W. B. (1989). Precise measurement of $\mathrm{G}+\mathrm{C}$ content of deoxyribonucleic aid by highperformance liquid chromatography. Int J Syst Bacteriol 39, 159-167. Pitcher, D. G., Saunders, N. A. \& Owen, R. J. (1989). Rapid extraction of bacterial genomic DNA with guanidium thiocyanate. Lett Appl Microbiol 8, 109-114.

Pot, B., Vandamme, P. \& Kersters, K. (1994). Analysis of electrophoretic whole-organism protein fingerprints. In Chemical Methods in Prokaryotic Systematics, pp. 493-521. Edited by M. Goodfellow \& A. G. O’Donnell. Chichester: Wiley.

Sahin, N., Isik, K., Tamer, A. U. \& Goodfellow, M. (2000). Taxonomic position of "Pseudomonas oxalaticus" strain $\mathrm{Oxl}^{\mathrm{T}}\left(\mathrm{DSM} 1105^{\mathrm{T}}\right)$ (Khambata and Bhat, 1953) and its description in the genus Ralstonia as Ralstonia oxalatica comb. nov. Syst Appl Microbiol 23, 206-209.

Sillman, C. E. \& Casida, L. E. (1986). Isolation of non-obligate bacterial predators from soil. Can J Microbiol 32, 760-762.

Steinle, P., Stucki, G., Stettler, R. \& Hanselmann, K. W. (1999).

Ralstonia basilensis sp. nov. In Validation of the Publication of New 
Names and New Combinations Previously Effectively Published Outside the IJSB, List no. 71. Int J Syst Bacteriol 49, 1325-1326.

Vandamme, P., Goris, J., Coenye, T., Hoste, B., Janssens, D., Kersters, K., De Vos, P. \& Falsen, E. (1999). Assignment of Centers for Disease Control group IVc-2 to the genus Ralstonia as Ralstonia paucula sp. nov. Int J Syst Bacteriol 49, 663-669.

Vaneechoutte, M., Kämpfer, P., De Baere, T., Falsen, E. \& Verschraegen, G. (2004). Wautersia gen. nov., a novel genus accommodating the phylogenetic lineage including Ralstonia eutropha and related species, and proposal of Ralstonia [Pseudomonas] syzygii (Roberts et al. 1990) comb. nov. Int J Syst Evol Microbiol 54, 317-327.

Yabuuchi, E., Kosako, Y., Yano, I., Hotta, H. \& Nishiuchi, Y. (1995).

Transfer of two Burkholderia and an Alcaligenes species to Ralstonia gen. nov.: proposal of Ralstonia pickettii (Ralston, Palleroni and Doudoroff 1973) comb. nov., Ralstonia solanacearum (Smith 1896) comb. nov. and Ralstonia eutropha (Davis 1969) comb. nov. Microbiol Immunol 39, 897-904.

Yabuuchi, E., Kawamura, Y., Kosako, Y. \& Ezaki, T. (1998). Emendation of the genus Achromobacter and Achromobacter xylosoxidans (Yabuuchi and Yano) and proposal of Achromobacter ruhlandii (Packer and Vishniac) comb. nov., Achromobacter piechaudii (Kiredjian et al.) comb. nov., and Achromobacter xylosoxidans subsp. denitrificans (Rüger and Tan) comb. nov. Microbiol Immunol 42, 429-438.

Zeph, L. R. \& Casida, L. E. (1986). Gram-negative versus Grampositive (actinomycete) bacterial predators of bacteria in soil. Appl Environ Microbiol 52, 819-823. 